\title{
Measuring the Technical Efficiency of Certified Organic Rice Producing Farms in Yasothon Province: Northeast Thailand
}

\author{
Nalun Panpluem ${ }^{1,2}$, Adnan Mustafa ${ }^{1} \mathbb{D}$, Xianlei Huang ${ }^{1}$, Shu Wang ${ }^{1}$ and Changbin Yin ${ }^{1, * \mathbb{C}}$ \\ 1 Institute of Agricultural Resources and Regional Planning, Chinese Academy of Agricultural Sciences, \\ Beijing 100081, China; pp.pilun@gmail.com (N.P.); adnanmustafa780@gmail.com (A.M.); \\ hxlzhg@sina.cn (X.H.); wangshu@caas.cn (S.W.) \\ 2 Department of Agriculture and Cooperatives, Sukhothai Thammathirat Open University, \\ Nonthaburi 11120, Thailand \\ * Correspondence: yinchangbin@caas.cn
}

Received: 17 October 2019; Accepted: 4 December 2019; Published: 6 December 2019

\begin{abstract}
Rice production holds a significant position in the Thai economy. Although it is the world's largest rice exporter, Thailand's increase in rice production is the result of an expansion in the cultivation area rather than an increase in yield per unit area. The present study was designed to estimate the technical efficiency and its governing factors for certified organic rice-growing farms in Yasothon Province, Thailand. A data envelopment model was employed to assess the technical efficiency of 328 farmer groups. The data revealed that the average technical efficiency was $23 \%$ and $28 \%$ under constant returns to scale (CRS) and variable returns to scale (VRS) specifications, respectively. Farmers can reduce the use of machinery, fertilizer, seed, and labor as input factors by about $80.1 \%, 25.62 \%, 24.72 \%$, and $19.15 \%$, respectively, while still achieving the same level of output. Multiple regression analysis was applied to estimate factors that affect the pure technical efficiency score (PTES) in the test regions. Results show that household size, farm size, water source, market accessibility, health symptoms, income, and labor were highly related to the TES and the amount of organic rice production. The regression coefficients of the predictors show that the income was the best predictor of the PTES at a significance level of $p<0.05$. It is concluded that the farmers can potentially increase their yields by up to $72 \%-77 \%$ under current management practices.
\end{abstract}

Keywords: pure technical efficiency score (PTES); data envelopment analysis; output-orientated; Yasothon Thailand; certified organic rice

\section{Introduction}

The excessive utilization of agrochemicals in conventional agricultural production settings can result in environmental degradation that ultimately threatens human health [1]. The continuous use of sole chemical fertilizers can exert several harmful effects on the soil environment, ground and surface water, and even the atmosphere, thus reducing the productivity of the soil by affecting its physical, chemical, and biological properties. Hence, the enhancement and maintenance of system productivity and resource use efficiency are essential for sustainable agriculture. It is well established that organic farming may solve these problems and has been considered one of the best options for protecting and sustaining soil health, and it is increasing in importance in present-day agriculture [2]. Many organic farming experiments have reported considerable improvements in soil physical quality and biological properties [3,4]. Moreover, organic agriculture enables ecosystems to better adjust to the changing climate while simultaneously improving the carbon sequestration potential of the soils [2]. 
Given the importance of organic farming and the growing demand for organically produced foods by consumers, organic rice production in Thailand has rapidly developed in the past decade. In 2017, organic agriculture in Thailand expanded by $21 \%$, of which organic rice production accounted for $28 \%$, and other integrated farming increased by $128 \%$ [5]. In 2016, about 9.93 thousand ha of cropland was planted with organic rice in Thailand, and 24.27 thousand tons of organic rice was produced (see Table 1). In Thailand, organic rice has been cultivated since ancient times. Because of the current and emerging trends of organic rice production, government agencies have continued to help farmers to fulfill control- and monitoring-based international standards of organic agriculture, such as the International Federation of Organic Agriculture Movements (IFOAM), United States Department of Agriculture (USDA), and the Organic Standards of the European Union (Council Regulation; EC). Moreover, a separate body of related agencies (such as the Rice Department, the Ministry of Agriculture and Cooperatives, in association with the Ministry of Commerce rice products for trade and export wing) allows for the use of the organic rice certification mark by selected organic rice-producing farms [6].

Table 1. Planting area and yield per ha under rice cultivation in 2016/2017 in Thailand.

\begin{tabular}{|c|c|c|c|c|c|c|c|}
\hline Area & Item & $\begin{array}{l}\text { Jasmine } \\
\text { Rice }\end{array}$ & $\begin{array}{l}\text { HomPathum } \\
\text { Rice }\end{array}$ & Paddy & $\begin{array}{c}\text { Sticky } \\
\text { Rice }\end{array}$ & $\begin{array}{l}\text { Colored Rice } \\
\text { and Organic } \\
\text { Rice }\end{array}$ & Total \\
\hline \multirow[t]{3}{*}{$\begin{array}{l}\text { Country } \\
\text { region }\end{array}$} & $\begin{array}{l}\text { Planting area } \\
\text { (thousand ha) }\end{array}$ & 4532.84 & 245.02 & 1966.47 & 2253.57 & 9.93 & 9007.83 \\
\hline & Yield (kg/ha) & 2193.75 & 4143.75 & 3587.50 & 2350.00 & 4700.00 & 2587.50 \\
\hline & $\begin{array}{c}\text { Production } \\
\text { (thousand tons) }\end{array}$ & 9937.40 & 1014.85 & 7051.86 & 5291.01 & 24.27 & $23,319.39$ \\
\hline \multirow[t]{3}{*}{$\begin{array}{l}\text { Northern } \\
\text { region }\end{array}$} & $\begin{array}{l}\text { Planting area } \\
\text { (thousand ha) }\end{array}$ & 547.74 & 63.72 & 921.57 & 439.52 & 3.02 & 1975.57 \\
\hline & Yield (kg/ha) & 3118.75 & 4043.75 & 3487.50 & 3587.50 & 6368.75 & 3425.00 \\
\hline & $\begin{array}{c}\text { Production } \\
\text { (thousand tons) }\end{array}$ & 1708.22 & 257.83 & 3216.66 & 1576.78 & 9.44 & 6768.94 \\
\hline \multirow{3}{*}{$\begin{array}{l}\text { Northeast } \\
\text { region }\end{array}$} & $\begin{array}{l}\text { Planting area } \\
\text { (thousand ha) }\end{array}$ & 3776.99 & 2.32 & 90.45 & 1809.78 & 4.61 & 5684.16 \\
\hline & Yield (kg/ha) & 2056.25 & 2531.25 & 2181.25 & 2043.75 & 4100.00 & 2056.25 \\
\hline & $\begin{array}{l}\text { Production } \\
\text { (thousand tons) }\end{array}$ & 7777.65 & 5.88 & 197.05 & 3703.20 & 9.32 & $11,693.10$ \\
\hline \multirow[t]{3}{*}{$\begin{array}{l}\text { Central } \\
\text { region }\end{array}$} & $\begin{array}{l}\text { Planting area } \\
\text { (thousand ha) }\end{array}$ & 206.09 & 173.87 & 920.36 & 4.26 & 1.58 & 1306.16 \\
\hline & Yield (kg/ha) & 2168.75 & 4237.50 & 3856.25 & 2581.25 & 5256.25 & 3637.50 \\
\hline & $\begin{array}{c}\text { Production } \\
\text { (thousand tons) }\end{array}$ & 447.49 & 737.12 & 3549.39 & 10.99 & 4.16 & 4749.15 \\
\hline \multirow[t]{3}{*}{$\begin{array}{l}\text { Southern } \\
\text { region }\end{array}$} & $\begin{array}{l}\text { Planting area } \\
\text { (thousand ha) }\end{array}$ & 2.01 & 5.10 & 34.10 & 0.02 & 0.72 & 41.95 \\
\hline & Yield (kg/ha) & 2006.25 & 2750.00 & 2600.00 & 2718.75 & 3912.50 & 2581.25 \\
\hline & $\begin{array}{c}\text { Production } \\
\text { (thousand tons) }\end{array}$ & 4.04 & 14.03 & 88.75 & 0.05 & 1.35 & 108.20 \\
\hline
\end{tabular}

Note: Cumulative data from 1 May 2016 to 15 September 2016.; Source: Department of rice, 2017 [7].

Although some achievements in organic rice production in Thailand have been made, there remain challenges, such as difficulty increasing organic rice yield by farmers, which is not conducive to the sustainability of organic rice production. Organic rice production in Thailand is a result of an expansion in the production area rather than an increase in yield per hectare. In 2016, the organic rice yield was $4700 \mathrm{~kg} / \mathrm{ha}$, accounting for approximately $1 / 2$ of the HomPathum rice yield (see Table 1). Yasothon Province of Northeast Thailand is an area of significant production of organic jasmine rice (unique fragrant characteristic scent). The efficiency of farmers who produce organic rice is still very low and facing biophysical (frequent floods, uneven rainfall, droughts, poor soil fertility, pest infestations), socioeconomic (low income related to high cost of production, unstable paddy prices, shortage of farm 
labor), and technological constraints (low-yielding conventional varieties) [8]. These constraints make organic rice cultivation different from conventional rice cultivation. For instance, in Thailand, the type and rate of fertilizers used in organic and conventional rice cultivation are much different [9]. It is well acknowledged that the application of chemical fertilizers produces higher grain yields than those produced with the organic fertilizers used in organic rice cultivation. Similarly, the soil under organic rice cultivation in Northeast Thailand is mostly salt-affected, which hinders the normal growth of rice plants and decreases its yield [10]. Moreover, in the northeastern region of Thailand, there is usually a rainy period following frequent droughts at regular intervals [11], making the rice plants vulnerable to drought stress. Collectively, these problems result in great differences between organic rice cultivation and conventional rice systems.

The production efficiency of farms requires maximum production without any waste [12]. Technical efficiency is the ability of a farmer to produce maximum output from given inputs [13]. The measurement of efficiency in agriculture is important because it provides a success indicator and a basis for performance assessment through which production units are evaluated. Previous studies have mentioned that the current production of rice at farms is below the ultimate output potentials [14], highlighting the need to increase production efficiency. There exists a gap between the actual yields obtained on farmer fields and the maximum attainable yield of certain rice varieties, and this deviation needs to be tackled for better and more efficient rice production on farms. Therefore, this study was planned to answer two main questions: (1) What are the crucial factors that affect the technical efficiency of organic rice-producing farms? (2) To what extent do these factors affect the amount of organic rice production?

Therefore, the specific objectives of the study were to quantify the technical efficiency observed on farms producing certified organic rice in Yasothon Province of Northeast Thailand to provide insights into the efficient utilization of farm input combinations under current rice farming practices and to evaluate the factors that affect the technical inefficiency of certified organic rice growers in the region. Furthermore, the results of this research are expected to be useful to organizations engaged in organic rice farming and can be advantageous for the promotion of organic rice production in other regions of the country. Given the scientific questions and objectives of the study, we formulated six hypotheses:

Hypotheses 1. The farmers producing certified organic rice are more technically efficient.

Hypotheses 2. The help received by the government has a significant positive impact on the pure technical efficiency score (PTES).

Hypotheses 3. Water sources have a significant positive impact on the PTES.

Hypotheses 4. Market accessibility has a significant positive impact on the PTES.

Hypotheses 5. Soil quality has a significant positive impact on the PTES.

Hypotheses 6. The socioeconomic characteristics (income, education, etc.) of the farmers affect the PTES.

\section{Materials and Methods}

\subsection{Data Sampling}

A survey was conducted in 2017-2018 to collect farm-level data from certified organic rice-growing farmers in Yasothon Province of Thailand (Figure 1a,b). Yasothon Province was chosen as the major province of organic farming. A comparison of the proportion of cultivated area to rice yield revealed that Yasothon Province has a high yield per cultivated area and is ranked at the top in the country [15]. Multistage cluster sampling was applied to collect the data [16]. A well-structured questionnaire was prepared, and 328 farmers from a total of 1811 were interviewed in seven districts of Yasothon Province, with a total area of 2485.6 ha [17]. The data were collected from 1 November 2017, to 30 March 2018 
using questionnaires and interviews with the certified organic rice farmers. A total of 328 farmers practicing organic rice farming were selected by the purposive sampling technique.

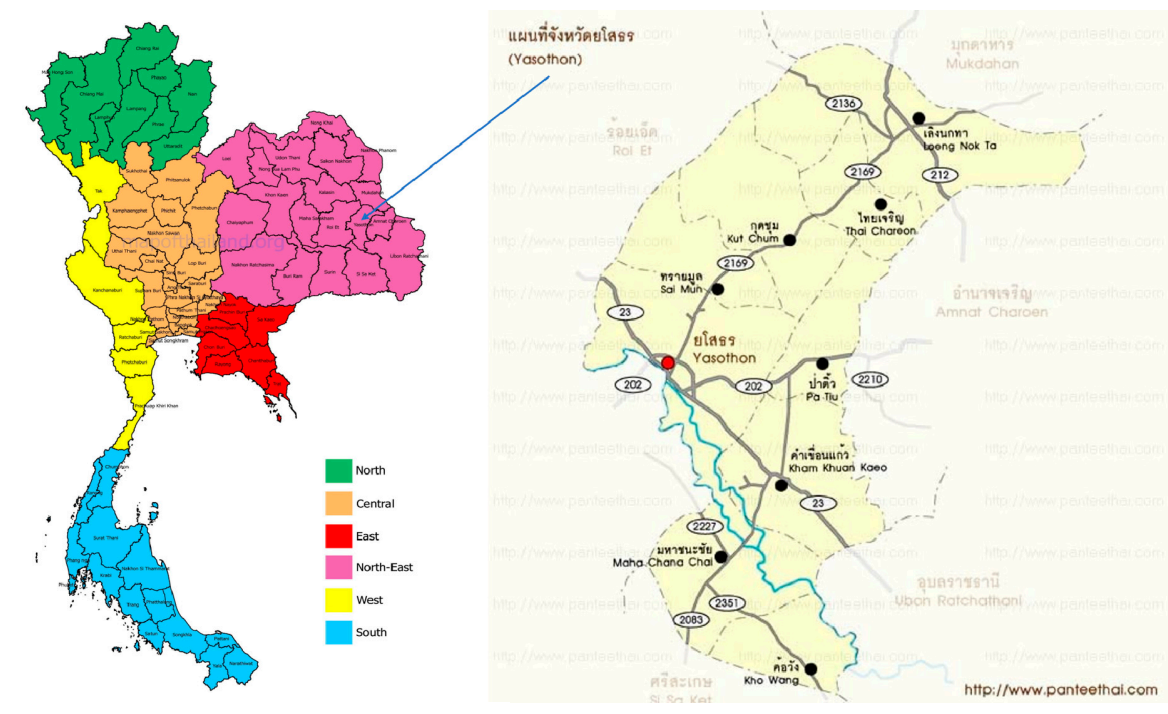

(a) Map of Thailand.

(b) Map of Yasothon Province

Figure 1. Study area comprising seven districts in Yasothon Province of Northeast Thailand.

In-depth interviews were conducted in seven districts of Yasothon Province, located in the northeast of Thailand, namely, KutChum, MahaChanaChai, PaTiu, KhoWang, LoengNokTha, SaiMun, and Muang. This area was chosen for its immense significance in rice production. Organic rice growers were mainly those who grow certified organic rice. These organic rice-producing farms have been monitored and accredited by the Organic Agriculture Certification Thailand (ACT) standards. The standards are supervised by The International Federation of Organic Agriculture Movements (IFOAM), EU: TH-BID-121 Thailand Agriculture, and Canada Organic Regime (COR).

\subsection{Model Specification}

Data envelopment analysis (DEA) is a linear programming technique for evaluating the technical efficiency of a set of members of peer decision-making units (DMUs), with multiple inputs and outputs under constant returns to scale (CRS) and variable returns to scale (VRS) [18]. In this study, DEA was used with the variable returns to scale (VRTS) technique. Return to scale (RTS) explains the behavior of the rate of increase in output (production) relative to the associated increase in the inputs (the factors of production) in the long term. In the long term, all factors of production are variable and subject to change due to a given increase in size (scale). Furthermore, RTS focuses on the relation between input and output quantities [19].

This method measures technical efficiency mainly by calculating a CRS model and a VRS model. It then computes scale efficiency.

The CRS model is as follows:

$$
\begin{aligned}
\max _{\varphi, \lambda} & \varphi_{c} \\
s t & -\varphi y_{i}+Y \lambda \geq 0, \\
x_{i}-X \lambda & \geq 0 \\
\lambda & \geq 0,
\end{aligned}
$$

where $\varphi_{c}$, is a constant measure of efficiency of the $i$ th decision-making unit $\left(\mathrm{DMU}_{i}\right)$, that is, the $i$ th firm, with $\varphi_{c}$, $<1$ denoting a loss of technical efficiency, $\lambda$ is a constant of an $\mathrm{N} \times 1$ vector, $y_{i}$ is the certified paddy rice yield of the $i$ th farmer, $x_{i}$ is the paddy rice production input of the $i$ th firm $(i=1, \ldots, \mathrm{M})$, 
$\mathrm{X}$ is an input matrix $\mathrm{M} \times \mathrm{N}$ vector, and $\mathrm{Y}$ is the certified organic jasmine rice yield per firm of a $1 \times$ $\mathrm{N}$ vector.

Some slackness may arise in the solutions using the CRS model. A two-stage estimation method was used to deal with this potential problem [20].

$$
\begin{array}{lr}
\min _{\lambda, O S, I S} & -\left(M 1^{\prime} O S+K 1^{\prime} I\right) \\
s t & -y_{i}+Y \lambda-O S=0 \\
& \varphi x_{i}-X \lambda-I S=0 \\
\lambda \geq 0, O S \geq 0, I S \geq 0,
\end{array}
$$

where $O S$ is a $1 \times 1$ vector of paddy rice yield error per farmer, $I S$ is an $\mathrm{M} \times 1$ vector of input errors, and $\mathrm{M} 1$ and $\mathrm{K} 1$ are $1 \times 1$ and $\mathrm{M} \times 1$ unity vectors, respectively.

The VRS model is as follows:

$$
\begin{aligned}
\max _{\varphi, \lambda} & \varphi_{v} \\
\text { st } & \\
-\varphi y_{i}+Y \lambda & \geq 0, \\
x_{i}-X \lambda & \geq 0, \\
N 1^{\prime} \lambda & =1 \\
\lambda & \geq 0
\end{aligned}
$$

where $\varphi_{v}$ is a constant measure of efficiency of the $i$ th farmer, $N 1$ is an $\mathrm{N} \times 1$ vector of 1 , and the other variables have the same meanings as in Equation (1).

The technical efficiency $\left(\varphi_{c}\right)$ obtained from the CRS model can be regarded as a combination of technical efficiency $\left(\varphi_{v}\right)$ and scale efficiency $\left(\varphi_{s}\right)$ derived from the VRS model (where $\varphi_{c}=\varphi_{v} \times \varphi_{s}$ ). Scale efficiency can be derived from $\varphi_{c}$ and $\varphi_{v}$ (where $\varphi_{s}=\varphi_{c} / \varphi_{v}$ ). When scale efficiency equals 1 , the production is at an optimal scale. When scale efficiency is less than 1 , the technical efficiency $\left(\varphi_{n}\right)$ of the non-increase returns to scale model (NIRS), as in Equation (4), can be calculated and compared with $\varphi_{v}$ to determine the returns to scale stage in which the production lies. When $\varphi_{n}$ is equal to $\varphi_{v}$, production is in a stage of decreasing returns to scale. When $\varphi_{n}$ is less than $\varphi_{v}$, production is in a stage of increasing returns to scale.

The concrete form of the NIRS is as follows:

$$
\begin{aligned}
\max _{\varphi, \lambda} & \varphi_{n}, \\
\text { st } & -\varphi y_{i}+Y \lambda \geq 0, \\
x_{i}-X \lambda & \geq 0, \\
N 1^{\prime} \lambda & =1 \\
\lambda & =0,
\end{aligned}
$$

The scale efficiency (SE) of farms can be formulated by dividing CRS technical efficiency (TE) by VRS TE. Technical efficiency under CRS can be acquired by removing the convexity constraint $\left(N 1^{\prime} \lambda=1\right)$ in Equation (4). Then, scale efficiency can be specified as follows:

$$
S E=\frac{T E_{C R S}}{T E_{V R S}}
$$

This is given a number of producers of 328 firms. One output is the yield of certified organic jasmine rice $(\mathrm{kg} / \mathrm{ha})$, and the four inputs are the seed $(\mathrm{kg} / \mathrm{ha})$, labor $(\mathrm{h} / \mathrm{ha})$, fertilizer $(\mathrm{kg} / \mathrm{ha})$, and machinery (h/ha) (see Table 4).

\subsection{Statistical Analysis}

The data analysis of this study was conducted using the computer-based software MaxDEA 7 LPSolve 5.5 to compute technical efficiency [21], Stata version 14.2. The primary data were collected from the sampled farmers using an interview schedule consisting of both open- and closed-ended 
questions. The data collected were analyzed by using descriptive statistics, namely, frequency and percentage. An inferential statistical tool and Tobit regression analysis were employed in the data analysis. Tobit regression analysis predicted the relationship between variables in the form of predictions [22]. We used a Tobit regression analysis model to identify the factors that affect the organic rice production using PTES and the variables $\mathrm{X}_{1}, \mathrm{X}_{2}, \ldots, \mathrm{X}_{17}$ when the variables have a linear relationship, as shown in the equation below:

$$
Y_{i}=\left\{\begin{array}{l}
L: Y_{i}^{*} \leq L \\
Y_{i}^{*} ; Y_{i}^{*}>L
\end{array}\right.
$$

where $Y_{i}^{*}, i=1, \ldots, n$, represents the link function created by a linear regression, and

$$
Y_{i}^{*}=\beta_{0}+\beta_{1} X_{1}+\beta_{2} X_{2}+\ldots+\beta_{17} X_{17}+\varepsilon_{i}
$$

The details for all variables involved in the regression analysis are given below:

Where $Y_{i}^{*}$ represents the pure technical efficiency score (PTES).

$\mathrm{X}_{1}, \mathrm{X}_{2}, \mathrm{X}_{3}, \ldots, \mathrm{X}_{17}$ is Independent variables, including $\mathrm{X}_{1}=$ Age, $\mathrm{X}_{2}=$ Gender, $\mathrm{X}_{3}=$ Junior high school, $X_{4}=$ Senior high school, $X_{5}=$ Household size, $X_{6}=$ Experience in organic, rice production, $X_{7}=$ Farm size, $X_{8}=$ Receiving help from the government, $X_{9}=$ Seed quality, $X_{10}=$ Soil quality, $X_{11}=$ Water source, $X_{12}=$ Land rent, $X_{13}=$ Modern technology, $X_{14}=$ Market accessibility, $\mathrm{X}_{15}=$ Health symptoms, $\mathrm{X}_{16}=$ Income, $\mathrm{X}_{17}=$ Labor (Table 2.).

$\beta_{0}$ is Constant term.

$\beta_{1}, \beta_{2}, \ldots, \beta_{17}$ is Coefficients to be estimated.

$\varepsilon_{\mathrm{i}}$ is Error term.

Table 2. List of variables used in the study.

\begin{tabular}{cccc}
\hline Variables & Description & AV & SD \\
\hline $\mathrm{X}_{1}=$ Age & Age of Farmers (year) & 54.729 & 9.306 \\
$\mathrm{X}_{2}=$ Gender & Gender (1: Male; 0: Female) & 0.412 & 0.493 \\
$\mathrm{X}_{3}=$ Junior high school & 1: Junior high school; 0: other & 0.107 & 0.076 \\
$\mathrm{X}_{4}=$ Senior high school & 1: Senior high school; 0: other & 0.309 & 0.266 \\
$\mathrm{X}_{5}=$ Household size & Family workforce that is responsible for rice & 2.009 & 0.657 \\
$\mathrm{X}_{6}=$ Experience in organic rice & production (person) & & \\
production & Organic Rice Production Experience (year) & 2.948 & 1.222 \\
$\mathrm{X}_{7}=$ Farm size & Farmers' owned land area (ha) & 2.457 & 1.575 \\
$\mathrm{X}_{8}=$ Receiving help from the & Received regular help (1: yes; 0: no) & 0.14 & 0.348 \\
government & Certified organic rice seed (1: yes; 0: no) & 0.104 & 0.305 \\
$\mathrm{X}_{9}=$ Seed quality & (s the soil fertile enough to support rice production? & 0.192 & 0.395 \\
$\mathrm{X}_{10}=$ Soil quality & (1: yes; 0: no) & 0.436 & 0.497 \\
$\mathrm{X}_{11}=$ Water source & Are the water resources sufficient (1: yes; 0: no) & 0.034 & 0.18 \\
$\mathrm{X}_{12}=$ Land rent & Is the land rent high? (1: yes; 0: no) & 0.14 & 0.348 \\
$\mathrm{X}_{13}=$ Modern technology & Use of modern technology (1: yes; 0: no) & 0.405 & 0.492 \\
$\mathrm{X}_{14}=$ Market accessibility & Easy access to market (1: yes; 0: no) & 0.188 \\
$\mathrm{X}_{15}=$ Health symptoms & Symptoms of allergic reactions, rashes (1: yes; 0: no) & 0.963 & 0.183 \\
$\mathrm{X}_{16}=$ Income & Annual household income (THB) & $63,943.86$ & $45,853.42$ \\
$\mathrm{X}_{17}=$ Labor & Availability of regular workers for labor & 1.555 & 0.657 \\
\hline
\end{tabular}

$\mathrm{AV}$, average; $\mathrm{SD}$, standard deviation.

First, the firm's efficiency, which is the dependent variable, is calculated. The value of efficiency ranges between 1 and 0 [23]. For the ith firm, Tobit analysis can be explained by the following mathematical expressions:

$$
Y_{i}^{*}=\beta X_{i}+\mu_{i}
$$


where $Y_{i}=Y_{i}^{*}$, with $Y_{i}^{*} \geq 0$, otherwise, $Y_{i}^{*} \leq 1$. $\beta$ is the set of parameters being measured, and $X_{i}$ is an explanatory variable. The error is denoted by $\mu_{i}$, and a latent variable is denoted by $Y_{i}^{*}$. $Y_{i}$ represents the efficiency of the $i$ th firm.

First, we used the DEA program to measure the efficiency of the firm. Then, we used the Statistical Package for Social Sciences software for the purpose of measuring the descriptive and illative statistics to determine the impact of an independent variable on the dependent variable (which is efficiency).

\section{Results}

\subsection{Descriptive Statistics}

Table 3 presents the summary statistics of the input variables for the production of rice. The general conditions of the farm operations of certified organic (jasmine) rice growers were collected by interviewing a sample of 328 organic rice producers in Yasothon Province, and the results were analyzed.

Table 3. Basic socioeconomic variables of farmers $(n=328)$.

\begin{tabular}{|c|c|c|}
\hline Variables & Frequency & Percentage \\
\hline \multicolumn{3}{|l|}{ Gender } \\
\hline Male & 138 & 42.07 \\
\hline Female & 190 & 57.93 \\
\hline \multicolumn{3}{|l|}{ Age } \\
\hline Less than 30 years & 2 & 0.61 \\
\hline 31-40 years & 13 & 3.96 \\
\hline $41-50$ years & 106 & 32.32 \\
\hline $51-60$ years & 109 & 33.23 \\
\hline $61-70$ years & 85 & 25.91 \\
\hline More than 70 years old & 13 & 3.96 \\
\hline \multicolumn{3}{|l|}{ Education level $(n=198)$} \\
\hline Not studying & 1 & 0.51 \\
\hline Primary school & 137 & 69.19 \\
\hline Junior High School/Vocational & 35 & 17.68 \\
\hline High School/Vocational & 16 & 8.08 \\
\hline Bachelor & 7 & 3.54 \\
\hline Master's degree & 2 & 1.01 \\
\hline \multicolumn{3}{|l|}{ Household size $(n=228)$} \\
\hline 1-2 persons & 62 & 27.19 \\
\hline $3-4$ persons & 108 & 47.37 \\
\hline 5-7 people & 51 & 22.37 \\
\hline More than 7 persons & 7 & 3.07 \\
\hline \multicolumn{3}{|l|}{ Experience in organic rice production } \\
\hline $1-2$ years & 63 & 19.21 \\
\hline $3-4$ years & 64 & 19.51 \\
\hline $5-6$ years & 28 & 8.54 \\
\hline More than 7 years & 173 & 52.74 \\
\hline \multicolumn{3}{|l|}{ Farm size } \\
\hline $0.16-0.8$ ha & 46 & 14.02 \\
\hline $0.96-1.6$ ha & 85 & 25.91 \\
\hline $1.76-2.4$ ha & 64 & 19.51 \\
\hline $2.56-3.2$ ha & 66 & 20.12 \\
\hline 3.36 ha or more & 67 & 20.43 \\
\hline \multicolumn{3}{|l|}{ Family workers * } \\
\hline Regular workers & 321 & 97.87 \\
\hline Temporary workers & 182 & 55.49 \\
\hline \multicolumn{3}{|l|}{ Receiving help from the government } \\
\hline Received regular help & 49 & 14.94 \\
\hline Was assisted infrequently & 279 & 85.06 \\
\hline
\end{tabular}

Note: * Farmers could choose more than one item. 
Most of the organic rice producers were female rather than male, with females accounting for $57.93 \%$ of the sample. Most of them were aged between 51 and 60 years (33.23\%), followed by $32.32 \%$ who were $41-50$ years old, and $25.91 \%$ who were $61-70$ years old. Further, $81.4 \%$ of organic rice growers had a primary school education, followed by $10.67 \%$ with junior high school/vocational training and $4.88 \%$ with secondary high school/vocational qualification. It is a worrying situation that low education is not conducive to mastering organic rice production technology. It was found that most (47.37\%) organic rice producers had three to four family members, followed by $27.19 \%$ with one to two family members and $22.37 \%$ with five to seven family members. The results show that $52.74 \%$ of organic rice growers had more than seven years of experience producing organic rice, followed by $19.51 \%$ with three to four years of experience and $19.21 \%$ with one to two years of experience. Most organic rice farmers (25.91\%) had areas of 0.96-1.6 ha under organic rice production, followed by $20.43 \%$ with an organic rice production area of over 3.36 ha and $20.12 \%$ with a production area of 1.76-2.4 ha. Most organic rice farmers (97.87\%) used regular labor to produce organic rice, and $55.49 \%$ used temporary labor. Most of the organic rice farmers $(85.06 \%)$ infrequently received regular government assistance, while only $14.94 \%$ received it regularly.

\subsection{Technical Efficiency}

The technical efficiency data obtained from the output-oriented (modified) DEA method for a total of 328 farms indicate that about 55 farms (representing 16.77\% of the total) were operating with constant returns to scale, whereas 249 farms, constituting the highest share $(75.91 \%)$, were found to be operating under increasing returns to scale, and about 24 farms $(7.32 \%)$ were operating under decreasing returns to scale (Figure 2).

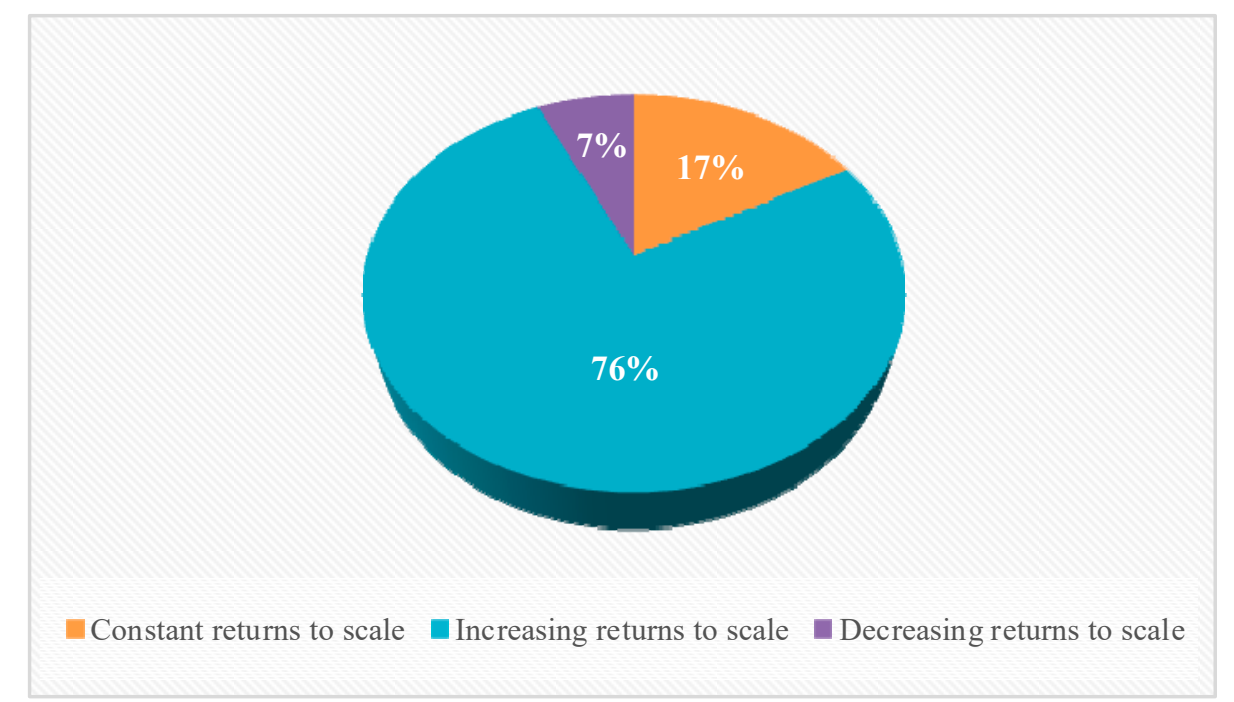

Figure 2. The returns to scale of certified organic rice-producing farms in Yasothon Province, Northeast Thailand.

The values of the input variables for certified organic rice-producing farms were determined: The average organic rice production was $2012.00 \mathrm{~kg} / \mathrm{ha}$, the average seed rate was $126.75 \mathrm{~kg} / \mathrm{ha}$, and the average labor was $25.75 \mathrm{~h} / \mathrm{ha}$ (Table 4). Moreover, the average amount of organic fertilizer used was $380.75 \mathrm{~kg} / \mathrm{ha}$, and the average machine operation for farming was $24.63 \mathrm{~kg} / \mathrm{ha}$. 
Table 4. Definition, measurement, and summary statistics of variables (per farm, $n=328$ ).

\begin{tabular}{ccc}
\hline Input and Output Variable & AV & SD \\
\hline Yield $(\mathrm{kg} / \mathrm{ha})$ & 2012.00 & 1349.56 \\
Seed $(\mathrm{kg} / \mathrm{ha})$ & 126.75 & 39.13 \\
Labor $(\mathrm{h} / \mathrm{ha})$ & 25.75 & 21.19 \\
Fertilizer $(\mathrm{kg} / \mathrm{ha})$ & 380.75 & 318.94 \\
Machinery $(\mathrm{h} / \mathrm{ha})$ & 24.63 & 16.44 \\
\hline AV, average; SD, standard deviation. &
\end{tabular}

Table 5 shows the frequency distribution of constant returns to scale (CRS) and variable returns to scale (VRS) efficiency estimates obtained by the two-stage DEA method. Inefficiency was found in the farming operations of the sampled farm households in the study area. The PTES under the CRS measure indicated a fully effective operation for three farms, and the efficiency values were below $40 \%$ for about 289 farms. On the other hand, the PTESs under the VRS measure indicated a fully effective operation for 12 farms, and the efficiency values were below $40 \%$ for about 261 farms. In addition, the average overall technical efficiencies ranged between 0.23 and 0.28 for CRS and VRS, respectively. This means that organic jasmine rice producers can increase their production efficiency by $72 \%-77 \%$. The average TE of rice farms from 2017 to 2018 was 0.89 . The maximum TE was 1.00, and the minimum TE was 0.18.

Table 5. The number of farms classified according to technical efficiency using the data envelopment analysis (DEA) method.

\begin{tabular}{cccc}
\hline Efficiency Scores & CRS & VRS & SE \\
\hline 1.00 & $3(0.91)$ & $12(3.66)$ & $55(16.77)$ \\
$0.90-0.99$ & $1(0.31)$ & $4(1.22)$ & $152(46.34)$ \\
$0.80-0.89$ & $1(0.31)$ & $4(1.22)$ & $52(15.850$ \\
$0.70-0.79$ & $3(0.91)$ & $3(0.91)$ & $45(13.72)$ \\
$0.60-0.69$ & $5(1.52)$ & $8(2.44)$ & $12(3.66)$ \\
$0.50-0.59$ & $9(2.74)$ & $13(3.96)$ & $6(1.83)$ \\
$0.40-0.49$ & $17(5.18)$ & $23(7.01)$ & $2(0.61)$ \\
$0.30-0.39$ & $36(10.98)$ & $28(8.54)$ & $2(0.61)$ \\
$0.20-0.29$ & $70(21.34)$ & $75(22.87)$ & $1(0.31)$ \\
$0.10-0.19$ & $149(45.43)$ & $132(40.24)$ & $1(0.31)$ \\
$0.00-0.09$ & $34(10.37)$ & $26(7.93)$ & $0(0.00)$ \\
Total & $\mathbf{3 2 8 ( 1 0 0 )}$ & $\mathbf{3 2 8 ( 1 0 0 )}$ & $328(\mathbf{1 0 0})$ \\
\hline Mean & 0.23 & 0.28 & 0.89 \\
Minimum & 0.01 & 0.01 & 0.18 \\
Maximum & 1 & 1 & 1 \\
SD & 0.16 & 0.23 & 0.13
\end{tabular}

Note: CRS, technical efficiency score; VRS, pure technical efficiency score; SE, scale efficiency.

The distribution of input slacks under the VRS specification is given in Table 6. It was found that the farmers were using inputs in excess, which demonstrates the ability to reduce the cost of input per farm without causing the overall production to decrease in any way. Farmers can reduce the use of machinery, fertilizer, seed, and labor as inputs by about $80.10 \%, 25.62 \%, 24.72 \%$, and $19.15 \%$, respectively, while still achieving the same level of output. The use of excess inputs by farms results in a lack of technical efficiency. Therefore, a farm's efficiency can be modified by referring to the use of production factors by farms that are comparatively technically efficient. 
Table 6. Distribution of input slacks.

\begin{tabular}{ccccc}
\hline Slacks (Input) & No. of Farms & Mean Slack & Mean Input Use & Excess Input Use (\%) \\
\hline Seed kg/ha & 204 & 25.13 & 101.63 & 24.72 \\
Labor h/ha & 66 & 4.13 & 21.63 & 19.15 \\
Fertilizer kg/ha & 107 & 77.63 & 303.13 & 25.62 \\
Machinery h/ha & 180 & 10.94 & 13.69 & 80.10 \\
\hline
\end{tabular}

\subsection{Factors Affecting the Pure Technical Efficiency Score (PTES)}

Table 7 shows the results of Tobit regression analysis for explanatory variables that are presumed to affect the amount of organic rice production, with basic socioeconomic conditions incorporated into the equation. The results show that factors such as junior high school education, farm size, water source, market accessibility, health symptoms, income, and labor had a significant relationship with the PTES: Junior high school education, farm size, water source, market accessibility, health symptoms, and labor had a significant negative impact on efficiency, whereas, income had a significant positive impact on efficiency.

Table 7. Tobit regression results of factors affecting the pure technical efficiency score (PTES).

\begin{tabular}{|c|c|c|c|c|c|}
\hline Variables & Coef. & Std. Error. & $t$ & $P>|t|$ & \\
\hline Constant & 0.441 & 0.084 & 5.25 & 0.000 & \\
\hline Age $\left(X_{1}\right)$ & -0.001 & 0.001 & -0.73 & 0.463 & \\
\hline Gender $\left(X_{2}\right)$ & 0.027 & 0.023 & 1.15 & 0.250 & \\
\hline Junior high school $\left(X_{3}\right)$ & -0.067 & 0.038 & -1.77 & 0.077 & * \\
\hline Senior above high school $\left(\mathrm{X}_{4}\right)$ & 0.028 & 0.046 & 0.61 & 0.541 & \\
\hline Household size $\left(X_{5}\right)$ & -0.018 & 0.014 & -1.31 & 0.192 & \\
\hline Experience in organic rice production $\left(\mathrm{X}_{6}\right)$ & 0.016 & 0.012 & 1.35 & 0.178 & \\
\hline Farm size $\left(X_{7}\right)$ & -0.011 & 0.002 & -6.98 & 0.000 & $* * *$ \\
\hline Receiving help from the government $\left(\mathrm{X}_{8}\right)$ & 0.035 & 0.036 & 0.96 & 0.337 & \\
\hline Seed quality $\left(X_{9}\right)$ & 0.005 & 0.044 & 0.11 & 0.916 & \\
\hline Soil quality $\left(\mathrm{X}_{10}\right)$ & -0.035 & 0.035 & -1.00 & 0.316 & \\
\hline Water source $\left(X_{11}\right)$ & -0.077 & 0.026 & -3.03 & 0.003 & $* *$ \\
\hline Land rent $\left(X_{12}\right)$ & -0.088 & 0.069 & -1.27 & 0.204 & \\
\hline Modern technology $\left(X_{12}\right)$ & -0.014 & 0.040 & -0.35 & 0.724 & \\
\hline Market accessibility $\left(\mathrm{X}_{13}\right)$ & -0.089 & 0.047 & -1.91 & 0.058 & * \\
\hline Health symptoms $\left(\mathrm{X}_{14}\right)$ & -0.103 & 0.035 & -2.90 & 0.004 & $* *$ \\
\hline Income $\left(\mathrm{X}_{15}\right)$ & 0.003 & 0.000 & 7.56 & 0.000 & $* * *$ \\
\hline Labor $\left(X_{16}\right)$ & -0.049 & 0.026 & -1.84 & 0.067 & * \\
\hline Sigma & 0.197 & 0.008 & & & \\
\hline Loglikelihood & & 45.033 & & & \\
\hline LR chi2(17) & & 0.290 & & & \\
\hline Total No. of observation & 328 & & & & \\
\hline
\end{tabular}

Note: ${ }^{*}, * *$, and ${ }^{* * *}$ represent significance at the levels of $10 \%, 5 \%$, and $1 \%$, respectively.

\section{Discussion}

\subsection{Technical Efficiency}

In this study, the analysis of technical efficiency using the DEA method revealed that $17 \%$ of organic rice-producing farms were operating under constant returns to scale. About $7 \%$ were found to exhibit decreasing returns to scale, and $76 \%$ were within increasing returns to scale [24]. Our results are supported by findings in the same northeast region in a similar (jasmine) rice-growing area in Chiang Mai Province of Thailand [25]. In our study, the average organic rice production was $2012.00 \mathrm{~kg} / \mathrm{ha}$, the seed rate was $126.75 \mathrm{~kg} / \mathrm{ha}$, the amount of labor used was $25.75 \mathrm{~h} / \mathrm{ha}$, the quantity of organic fertilizer used was $380.75 \mathrm{~kg} / \mathrm{ha}$, and the average machine operation for organic rice cultivation 
was $24.63 \mathrm{~kg} / \mathrm{ha}$. These results are similar to the findings in [26], although that study reported lower values. The results in this study are contrary to previous research that reported an average organic rice production $(1932.25 \mathrm{~kg} / \mathrm{ha})$ and seed rate $(68.81 \mathrm{~kg} / \mathrm{ha})$ that were lower than our results, with higher values reported for the amount of labor used $(140.19 \mathrm{~kg} / \mathrm{ha})$, the amount of organic fertilizer used $(2838.81 \mathrm{~kg} / \mathrm{ha})$, and the average machine operation for organic rice farming $(66.50 \mathrm{~kg} / \mathrm{ha})$ [5]. In contrast, the results of our study are in accordance with previous research that studied some of the factors discussed herein. The authors reported that the rice production output was $2034.38 \mathrm{~kg} / \mathrm{ha}$, the average seed rate was $109.63 \mathrm{~kg} / \mathrm{ha}$, the average amount of organic fertilizer used was $590.06 \mathrm{~kg} / \mathrm{ha}$, and the average labor for rice farming was $45.44 \mathrm{~kg} / \mathrm{ha}$. However, although these results are similar to the findings in [2], the current research on the efficiency of organic rice production is rare. Because of the low efficiency of organic rice production in Thailand, the yield of organic rice is relatively low compared with the organic rice production in India (more than double the yield).

In addition, the average overall technical efficiencies in the present study were 0.23 and 0.28 for CRS and VRS, respectively [27]. These are contrary to previous studies that reported greater values $(C R S=0.41$, VRS $=0.54)$, possibly because of the wise management of each production factor. In principle, increases in rice output of $72 \%$ and $77 \%$ will decrease inefficiency. Under the prevailing conditions, about $17 \%$ of farms were identified as technically fully efficient. The observed difference between the CRS and VRS measures further indicates that some of the farmers did not operate at an efficient scale, and improvement in the overall efficiencies could be achieved if the farmers adjust their scales of operation. Of the studied farms, a technical efficiency score within 0.80-0.99 was the rarest under the CRS specification. Under the VRS, the rarest score was within 0.70-0.79. This further reflects that TE scores were higher under the VRS than those obtained under the CRS specification [28]. These findings are in line with those in [25]. The majority of farmers were experiencing increasing returns to scale. By operating at an optimal scale (CRS), input waste could be reduced.

The above-mentioned technical inefficiencies may be called radial technical inefficiency (or the inefficiencies of production units that are lower than the production frontier). If these inefficiencies were eliminated, all the farmers would have been on the border of production. However, some farmers were not yet technically efficient. They could still improve the use of production factors wisely without changing the amount of yield. In other words, the growers experienced problems involving the excess use of input slacks. Farmers who grow organic rice need to improve the practices and application methods of production factors [25,29]. When operating with a CRS, these types of farmers could be more competitive since their reduced costs would probably translate to increased profit [30]. Enhancing rice yield per ha under the current management could be achieved by improving production factors that will increase the technical efficiency of farmers. For example, machinery power is a significant factor for increasing rice yield.

The wise utilization of machinery at the farm level ensures the adoption of labor-saving operations for rice production to recompense the scarcity of manual labor. The use of labor-saving technology and the wise management of machinery over the last 20 years have slightly improved the technical efficiency of rice production in Thailand. However, it is still lower than the maximum potential [19]. It is suggested that extension workers visit farmers to guide them in the best practices for managing inputs. This could result in the enhancement of technical, allocative, and economic efficiency for these rice farmers and thus increase production and yield to meet food security needs, which is the most important issue worldwide [31]. We recommend the following. First, attention should be paid to zoning areas for rice production and land holdings to improve farmers' efficiency performance, which is the most valuable resource to manage. Second, the government should focus on useful policies to support facilities, modern agricultural machinery, and training on advanced technology for farmers so that they can acquire new knowledge and new machinery to develop their own farms. 


\subsection{Factors Affecting the Pure Technical Efficiency Score (PTES)}

The results of this study show that the variables (Table 1) were highly related to the pure technical efficiency score (PTES). These results are in line with earlier findings that implied that the level of education was highly associated with the production of organic rice and that most organic rice producers were female. One probable reason behind this finding is that middle-aged women with junior high school education reside in the countryside and often work in agriculture. Moreover, they may belong to families with farming as their main career, with no additional occupation [5,32]. Similar to our results are the findings of [32] for other regions of Thailand. Most of them were engaged as regular workers for farms, which might be because people aged between 21 and 30 years have more experience in farming [33,34]. Furthermore, farmers with more than seven years of experience in organic rice production are likely to be declared certified organic rice-producing farms according to standards for export [35]. Additionally, operating farms by using family labor instead of hiring contractors can save production costs, which will contribute to technical efficiency. Organic farming requires more manual labor than conventional farming. Consequently, households with a larger number of family laborers are more likely to adopt organic farming [36]. In addition, many organic rice farmers of Yasothon Province of Thailand in this study had a small farm size, which ranged between 0.96 and $1.6 \mathrm{ha}$, and rice cultivation generated their main income; thus, they maintained a balance between income and expenditure [37]. Most of the farmers owned an area of less than 1.6 ha. This finding further reveals the adoption of small-scale rice farming in the studied area, defined as less than 2 hectares of cropland by the World Bank [30]. The average total land size per family was approximately $2.81 \mathrm{ha}$, which is lower than the average of the country (3.61 ha) and of the Northeastern region (3.40 ha) [38]. Moreover, this farmland was divided into two to three paddy plots or more. The average rice farm size is about 2.50 ha [11]. Therefore, the larger rice farm is considered to be technically more efficient than the smaller one because of the advantage of a respective economy scale. However, farm size expansion in the current era seems to be difficult or nearly impossible because of the overwhelming increase in population and limited areas for expansion.

Furthermore, the coefficient of farm size was found to be negative and statistically non-significant. This suggests that a negative relationship between productivity and farm size existed in the present study. However, this further suggests that the output of rice will increase if rice farmers increase their farm size. This finding also agrees with the outputs of numerous research works, such as Jirarud [39] and Fakkhong and Suwanmaneepong [38]. Most jasmine rice farms are located in rainfed areas. Nevertheless, some farms are engaged in small irrigation projects, while most non-contract organic farms are located in rainfed areas without access to water during dry seasons $[11,40,41]$. Similarly, an increase in water management and an increase in tube wells can lead to an increase in yield. These findings suggest that the government should provide irrigation systems strengthened by extension services on water management techniques in the study area. In other words, wise water management is a sustainable means of supporting the future of organic rice production in Thailand [32]. Similarly, irrigation systems, water management, and tube wells showed a significant positive relationship with income levels at the 5\% significance level. This indicates that an increase in the adoption of modern irrigation systems (i.e., increase in water management and increase in tube wells) leads to an increase in yield and hence increases income from rice sales [42].

In addition, off-farm income generates more income than non-farm or on-farm [40]. Households with higher farm incomes have been shown to be more efficient. This suggests that improving farm income can also improve rice production efficiency. Therefore, a policy to raise or guarantee the price of agriculture commodities is an alternative option. This would stabilize or improve farm household income, which would thus make them more efficient rice producers [43]. The promotion of organic paddy markets at the local level, with fair trading and price guarantees, as well as organic rice markets in the country, is also necessary [11]. Additionally, market distance has a significant influence: A shorter market distance is likely to reduce translocation costs and improve access to market information [44]. Economic factors, such as the guaranteed access to the market, have 
also ranked as high influencers [41]. Female farmers have especially played a role in the production process of organic rice through maintenance, management, training, and processing of rice produced. It is well known that participation in farmer training programs helps producers to gain more knowledge related to organic rice production. Accordingly, farmers participating in related training programs are likely to increase their technical efficiency of organic rice production [44].

Finally, health symptoms related to illness caused by chemical allergies were found in few farmers cultivating rice in the test region. This might be the outcome of reduced use of chemical fertilizers and pesticides because they have adopted organic agricultural practices. The population attributed healthier properties to the consumption of organic food. Although scientific evidence is still scarce, organic agriculture seems to contribute to the maintenance of optimal health and the decreased risk of developing chronic diseases [45]. This may be the result of the higher content of bioactive compounds and lower content of unhealthy substances, such as cadmium and synthetic fertilizers and pesticides, in organic foods of plant origin compared with conventional agricultural products [46].

\section{Conclusions}

Technical efficiency reflects the ability of the production unit to produce the highest output from existing production factors or the potential to reduce the use of production factors. The results of this study indicate that certified organic rice-producing farms in Yasothon Province had an average organic rice production output of $2012.00 \mathrm{~kg} / \mathrm{ha}$. The average seed rate was $126.75 \mathrm{~kg} / \mathrm{ha}$, the average labor for organic rice farming was $25.75 \mathrm{~h} / \mathrm{ha}$, the average amount of organic fertilizer used was $380.75 \mathrm{~kg} / \mathrm{ha}$, and the average machinery for organic rice farming was $24.63 \mathrm{~kg} / \mathrm{ha}$. Therefore, the conclusion of the present study is that the interviewed farmers have a low level of efficiency in resource utilization. With the present technology in Yasothon Province, rice production can be increased by about $72 \%$ and $77 \%$ for enhanced technical efficiency under the CRS and VRS specifications, respectively. The majority of the farmers were experiencing increasing returns to scale. By operating at an optimal scale, input waste could be reduced. The value of excess input use demonstrates the ability to reduce the cost of input per farm. Farmers can reduce the use of machinery, fertilizers, seed, and labor as inputs by about $80.10 \%, 25.62 \%, 24.72 \%$, and $19.15 \%$, respectively. In addition, the factors that influence efficiency were analyzed by applying multiple regression with the PTES, and the results showed that the PTES was significantly affected by seven factors: Household size, farm size, water source, market accessibility, health symptoms, income, and labor. The $\mathrm{R}^{2}$ value (0.258) indicates that socioeconomic and agricultural extension factors could explain $25.8 \%$ of the variance of rice production in this area. Thus, extension services should be optimized to increase the technical efficiency of these inefficient farms in Yasothon Province. Furthermore, this study can provide critical information to farmers, agricultural planners, and Thai government departments to determine strategies that are useful and practical for raising efficiency performance in each region and increasing the trend of the rice productivity index in some areas of Thailand.

We observed some limitations of this research that should be noted. On the one hand, the estimated perceptions of farmers were not robust enough to apply to other provinces of Thailand because the survey was carried out in only one province. Yasothon Province is in Northeast Thailand, and its circumstances are much different from those in other regions. Therefore, more surveys should be conducted in different provinces to strengthen the reliability and applicability of the present findings. On the other hand, the results of this study emphasize that cooperation between all sectors is a key factor that drives the amount of organic rice production toward sustainable organic rice production, but this is just a matter of beginning the process. Additionally, other factors, such as diseases that arise from certified organic planting, should be taken into consideration.

Author Contributions: All authors were involved in preparing the manuscript. Conceptualization, N.P. and C.Y.; funding acquisition, N.P.; methodology, N.P.; supervision, C.Y.; data curation, N.P.; writing-original draft, N.P. and A.M.; writing - review and editing, A.M., X.H., S.W. and C.Y. 
Funding: This research was funded by the Major Program of the National Social Science Foundation of China, grant number 18ZDA048; China Agriculture Research System-Green Manure, grant number CARS-22-G-25 and the China Scholarship Council (CSC), grant number 2017SLJ022668.

Acknowledgments: The authors are highly thankful to the Department of Agriculture and Cooperatives, Sukhothai Thammathirat Open University, Nonthaburi 11120, Thailand.

Conflicts of Interest: The authors declare no conflict of interest.

\section{References}

1. Mustafa, A.; Naveed, M.; Saeed, Q.; Ashraf, M.N.; Hussain, A.; Abbas, T.; Kamran, M.; Minggang, X. Application Potentials of Plant Growth Promoting Rhizobacteria and Fungi as an Alternative to Conventional Weed Control Methods. In Crop Production; IntechOpen: London, UK, 2019. [CrossRef]

2. Surekha, K.; Rao, K.V.; Shobha, R.N.; Latha, P.C.; Kumar, R.M. Evaluation of Organic and Conventional Rice Production Systems for their Productivity, Profitability, Grain Quality and Soil Health. Agrotechnology 2013. [CrossRef]

3. Pathak, H.; Kushwala, J.S.; Jain, M.C. Eyahiation of manurial value of Biogas spent slurry composted with dry mango leaves, wheat straw and rock phosphate on wheat crop. J. Indian Soc. Soil Sci. 1992, 40, 753-757.

4. Carpenter, B.L.; Kennedy, A.C.; Reganold, J.P. Organic and biodynamic management effects on soil biology. Soil Sci. Soc. Am. J. 2000, 64, 1651-1659. [CrossRef]

5. Kerdsriserm, C.; Suwanmaneepong, S.; Mankeb, P. Comparative analysis of the technical efficiency of different production systems for rice farming in Eastern Thailand. Asian J. Sci. Res. 2018, 11, 480-488.

6. Department of Foreign Trade. Available online: http://www.dft.go.th/en-us/ (accessed on 10 May 2019).

7. Department of Rice. 2017. Available online: https://www.thairicedb.com/ (accessed on 10 September 2019).

8. OAE. Poverty Incidence of Southern Agricultural Household in Crop. Year 1998/1999; Office of Agricultural Economics: Bangkok, Thailand, 2000. (In Thai)

9. Kunlanit, B.; Sriboonrote, W. Fertilizer Management on Growth, Yield and Economic Return of Rice cv. Khao Dawk Mali 105 Production. Available online: paj.rmu.ac.th/journal/home/journal_file/127.pdf (accessed on 8 November 2019).

10. Wongsritha, S.; Panchaban, S.; Katavatin, R.; Ta-aun, M. Effect of Salinity Levels, Organic and Chemical Fertilizer on Growth, Yield and Grin Quality of KDML 105 Rice Variety. KKU Res. J. (GS) 2005, (Suppl. S5), 103-112.

11. Pornpratansombat, P.; Bauer, B.; Boland, H. The Adoption of Organic rice Farming in Northeastern Thailand. J. Org. Syst. 2011, 6, 4-12.

12. Ajibefun, I.A.; Daramola, A.G. Determinants of Technical and Allocative Efficiency of Micro-Enterprises: Firm-Level Evidence from Nigeria; African Development Bank: Abidjan, Ivory Coast, 2003; pp. 353-395.

13. Elhendy, A.M.; Alkahtani, S.H. The resource use efficiency of conventional and organic date farms in Saudi Arabia: A data envelopment analysis approach. J. Anim. Plant. Sci. 2013, 23, 596-602.

14. Pochatan, S. Technical Efficiency of Rice Production in Thailand. Ph.D. Thesis, Ramkhamhaeng University, Bangkok, Thailand, 2005.

15. Office of Agricultural Economics. 2018. Available online: http://www.oae.go.th/ (accessed on 10 May 2018).

16. Yasothon Provincial Office. 2018. Available online: http://www.yasothon.go.th/ (accessed on 10 May 2018).

17. Yamane, T. Statistics, An Introductory Analysis, 2nd ed.; Harper and Row: Manhattan, NY, USA, $1967 ;$ p. 886.

18. Charnes, A.; Cooper, W.W.; Rhodes, E. Measuring the efficiency of decision making units. Eur. J. Oper. Res. 1978, 2, 429-444. [CrossRef]

19. Rizwan, M.; Deyi, Z.; Osti, R.; Nazir, A.; Ahmed, U.I.; Gao, G. Measuring economic efficiency among rice farmers through non-parametric approach in Punjab Pakistan. J. Environ. Agric. Sci. 2017, 12, $35-43$.

20. Coelli, T.J. A Guide to DEAP Version 2.1: A Data Envelopment Analysis (Computer) Program; Centre for Efficiency and Productivity Analysis Department of Econometrics University of New England: Armidale, Australia, 1996.

21. Berkelaar, M.; Eiklan, K.; Dirks, J.; Notebaert, P. Max DEA 7 Manual. Beijing Realworld Software Company Ltd., 2018. Available online: http://maxdea.com (accessed on 20 March 2019). 
22. Thipbharos, T. Application of Tobit-piecewise Regression in Economics Data Consisting of Outliers. Suthiparithat 2015, 29, 47-63.

23. Ahmad, M.F.; Ishtiaq, M.; Hamid, K.; Khurram, M.U.; Nawaz, A. Data Envelopment Analysis and Tobit Analysis for Firm Efficiency in Perspective of Working Capital Management in Manufacturing Sector of Pakistan. Int. J. Econ. Financ. Issues 2017, 7, 706-713. [CrossRef]

24. Krasachat, W. Technical efficiencies of rice farms in Thailand: A non-parametric approach. J. Am. Acad. Bus. Camb. 2004, 4, 64-69.

25. Chauanphoonphon, Y.; Wibunphong, A.; Sriboonjit, S. Technical Performance of Rice Growers in Irrigated Areas Chiang Mai Province; Research Center to Increase Agricultural Productivity Faculty of Agriculture, Chiang Mai University: Chiang Mai, Thailand, 2005.

26. Singhapreecha, C.; Songsrirote, N. The measurement of technical efficiency on certified organic jasmine rice farms. Kasetsart Univ. J. Econ. 2007, 14, 31-45.

27. Kallika, T.; Ismail, A.L.; Mad, N.S. A Nonparametric Approach to Evaluate Technical Efficiency of Rice Farms in Central Thailand. Chulalongkorn J. Econ. 2010, 22, 1-14.

28. Suebpongsakorn, A. Data Envelopment Analysis (DEA) methodology and technical performance measurement. CMU J. Econ. 2012. Available online: https://www.econ.cmu.ac.th/econmag/journals/ issue16-1_3.pdf (accessed on 5 December 2019).

29. Sharma, K.R.; Laung, P.S.; Zaleski, H.M. Technical, Allocative and Economic Efficiencies in Swine Production in Hawaii: A comparison of Parametric and Non parametric Approaches. Agric. Econ. 1999, 20, $23-35$. [CrossRef]

30. Julius, A.; Chukwumah, A.F. Socio-economic Determinants of Small-scale Rice Farmers' Output in Abuja, Nigeria. Asian J. Rural. Dev. 2014, 4, 16-24. [CrossRef]

31. Parichatnon, S.; Maichum, K.; Peng, K.C. Evaluating Technical Efficiency of Rice Production by Using A Modified Three-Stage Data Envelopment Analysis Approach: A Case Study in Thailand. Int. J. Sci. Technol. Res. 2017, 6, 152-159.

32. Kerdsriserm, C.; Suwanmaneepong, S.; Mankeb, P. Factors Affecting Adoption of Organic Rice Farming in Sustainable Agriculture Network, Chachoengsao Province, Thailand. Int. J. Agric. Technol. 2016, 12, 1227-1237.

33. Dhungana, B.R.; Nuthall, P.L.; Nartea, G.V. Measuring the economic inefficiency of Nepalese rice farms using data envelopment analysis. Aust. J. Agric. Resour. Econ. 2004, 48, 347-369. [CrossRef]

34. Obasi, P.C.; Henri-Ukoha, A.; Ukewuihe, I.S.; Chidiebere-Mark, N.M. Factors Affecting Agricultural Productivity among Arable Crop Farmers in Imo State, Nigeria. Am. J. Exp. Agric. 2013, 3, 443-454. [CrossRef]

35. OAE. Agricultural Statistics of Thailand 2008. Office of Agricultural Economics: Bangkok, 2009. Available online: http://www.oae.go.th (accessed on 13 May 2019).

36. Organic Agriculture Certification Thailand. Organic Agriculture Certification Service. Available online: http://www.actorganic-cert.or.th (accessed on 23 May 2018).

37. Klinchan, A. The Study Cost and Returns of Organic Rice Cultivation in Phetchabun; National Research Council of Thailand: Bangkok, Thailand, 2014.

38. Fakkhong, S.; Suwanmaneepong, S. Socio-Economic Factors Influencing Rice Production in PeriUrban Area, Bangkok, Thailand. J. Agric. Technol. 2015, 11, 2053-2062.

39. Jirarud, S.; Suwanmaneepong, S.; Mankeb, P. Farmer and Farm Characteristics Affecting Rice Production on Large Agricultural Plot Scheme: A Case of Khlong Khuean District, Chachoengsao Province, Thailand. Int. J. Agric. Technol. 2016, 12, 1821-1831.

40. Nurliza, D.E.; Yusra, A.H.A. Rice Farming Performance for Sustainable Agriculture and Food Security in West Kalimantan. J. Agribus. Rural Dev. Res. 2017, 3, 84-92. [CrossRef]

41. Jierwiriyapant, P.; Liangphansakul, O.; Chulaphun, W.; Pichaya-satrapongs, T. Factors Affecting Organic Rice Production Adoption of Farmers in Northern Thailand. CMU. J. Nat. Sci. Spec. Issue Agric. Nat. Resour. 2012, 11, 327-333.

42. Ibrahim, A.A.; Mustapha, S.B.; Nuhu, S.H. Effects of Adoption of Rice Production Technologies on Farmers' Income in Borno State. Niger. J. Agric. Vet. Sci. 2012, 1, 19-22. 
43. Srisompun, O.; Isvilanonda, S. Efficiency change in Thailand rice production: Evidence from panel data analysis. J. Dev. Agric. Econ. 2012, 4, 101-108. [CrossRef]

44. Chandio, A.A.; Yuansheng, J. Determinants of Adoption of Improved Rice Varieties in Northern Sindh, Pakistan. Available online: http://www.sciencedirect.com (accessed on 25 February 2018).

45. Rembiałkowska, E.; Średnicka, D. Organic food quality and impact on human health. Agron. Res. 2009, 7, 719-727.

46. Barroso, S.H.; Rimbau, A.T.; Queralt, A.V.; Raventós, R.M.L. Organic food and the impact on human health. Crit. Rev. Food Sci. Nutr. 2017. [CrossRef]

(C) 2019 by the authors. Licensee MDPI, Basel, Switzerland. This article is an open access article distributed under the terms and conditions of the Creative Commons Attribution (CC BY) license (http://creativecommons.org/licenses/by/4.0/). 